\title{
EFEKTIVITAS PEMBELAJARAN PENDEKATAN SAINTIFIK TERHADAP KEMAMPUAN BERPIKIR KRITIS SISWA \\ (Studi Kuasi Eksperimen pada Mata Pelajaran IPS Kelas VII D di SMPN 1 Pacet - Cianjur)
}

\author{
${ }^{1}$ Firman Sanjaya \\ ${ }^{1}$ Pendidikan Ekonomi FKIP Universitas Pasundan
}

\begin{abstract}
Penelitian ini dilatarbelakangi oleh belum optimalnya pembelajaran IPS dalam meningkatkan kemampuan berpikir kritis peserta didik. Penelitian ini dilaksanakan di SMPN 1 Pacet Cianjur kelas VII D. Metode penelitian yang digunakan adalah metode kuasi eksperimen dengan desain penelitian kelompok tunggal pre-test dan post test. Tujuan dilakukan penelitian ini untuk mengetahui perbedaan kemampuan berpikir kritis siswa pada pengukuran awal (pre-test) dan setelah pengukuran (post test). Hasil penelitian menunjukan bahwa dengan menerapakan pembelajaran pendekatan saintifik, dapat memberikan kontribusi yang signifikan terhadap kemampuan berpikir kritis peserta didik. Secara statistik ada perbedaan antara nilai pada saat pre- test dan post test. Dengan demikian maka dapat disimpulkan bahwa pembelajaran pendekatan saintifik merupakan salah satu model pembelajaran efektif yang dapat digunakan untuk meningkatkan kemampuan berpikir peserta didik. Berdasarkan hasil penelitian, untuk memperoleh hasil yang lebih maksimal dalam peningkatan kemampuan berpikir kritis peserta didik, maka dianjurkan untuk menerapkan pembelajaran pendekatan saintifik pada mata pelajaran IPS dengan memperhatikan perbedaan individu yang beorientasi kepada kemampuan berpikir kritis yang santun, dan membuat perangkat pembelajaran yang disesuaikan dengan kebutuhan peserta didik.
\end{abstract}

Kata Kunci: pendekatan saintifik, berpikir kritis

\section{PENDAHULUAN}

Pendidikan merupakan ujung tombak kemajuan sebuah bangsa. Bangsa akan menjadi maju apabila memiliki sumber daya manusia (SDM) yang berkualitas atau bermutu tinggi. Adapun mutu bangsa di kemudian hari tergantung pada pendidikan yang dikecap oleh anakanak sekarang, terutama melalui pendidikan formal yang diterima di sekolah.

Kualitas pendidikan di Indonesia saat ini sangat memprihatikan. Ini dibuktikan antara lain dengan data UNESCO (2000) tentang peringkat indeks pengembangan manusia (Human Development Index), yaitu komposisi dari peringkat pencapaian pendidikan, kesehatan, dan penghasilan per kepala yang menunjukan bahwa indeks pengembangan manusia Indonesia makin menurun, di antara 174 negara di dunia, Indonesia menempati urutan ke-102 (1996), ke-99 (1997), ke-105 (1998), dan ke-109 (1999). Menurut survey Political and Economic Risk Consultant (PERC), kualitas pendidikan Indonesia berada pada urutan ke-12 dari 12 negara di Asia. Data yang dilaporkan The World Economic Forum Swedia (2000), Indonesia memiliki daya saing yang rendah, yaitu hanya menduduki urutan ke-37 dari 57 negara di dunia. Dan berdasarkan data dari The Learning Curve Pearson 2014 pada mei silam, Indonesia menempati urutan terakhir dari 40 negara dalam mutu pendidikan, Indonesia menjadi negara dengan mutu pendidikan terpuruk dibawah Meksiko, Brasil, Argentina, Kolombia, dan Thailand.

Dalam menyukseskan pendidikan banyak hal yang harus diperhatikan, diantaranya kebijakan pemerintah yang seharusnya memihak kepada masyarakat, anggaran dana pendidikan direalisasikan $20 \%$ dari APBN, visi, misi, dan tujuan pendidikan yang jelas sehingga 
dapat meningkatan profesionalisme guru, sarana prasarana belajar yang memadai serta kurikulum yang matang dan mudah diakses oleh seluruh pelaksana pendidikan di berbagai satuan pendidikan dasar dan menengah.

Beberapa hal diatas, dalam proses pendidikan kurikulum sangat berperan dalam memandu proses belajar mengajar sesuai dengan tujuannya yang penting. Sesuai dengan tujuan pendidikan nasional yang tersurat pada UU no 20 tahun 2003 tentang pendidikan nasional bab X pasal 36 Yang berbunyi:

(1) Pengembangan kurikulum dilakukan dengan mengacu pada standar nasional pendidikan untuk mewujudkan tujuan pendidikan nasional.

(2) Kurikulum pada semua jenjang dan jenis pendidikan dikembangkan dengan prinsip diversifikasi sesuai dengan satuan pendidikan, potensi daerah, dan peserta didik.

Ibarat tubuh, kurikulum merupakan jantungnya pendidikan. Kurikulum menentukan jenis dan kualitas pengetahuan dan pengalaman yang memungkinkan orang atau seseorang mencapai kehidupan dan penghidupan yang lebih baik.

Sejarah Kurikulum Pendidikan di Indonesia, sejak Indonesia merdeka kurikulum telah mengalami beberapa beberapa kali perubahan secara berturut-turut yaitu pada tahun 1947, tahun 1952, tahun 1964, tahun 1975, tahun 1984, tahun 1994, tahun 2004, tahun 2006, dan yang terbaru kurikulum tahun 2013. Dinamika tersebut merupakan konseksuensi logis dari terjadinya perubahan sistem politik, sosial budaya, ekonomi, IPTEK, dalam masyarakat berbangsa dan bernegara. Sebab kurikulum sebagai perangkat rencana pendidikan perlu dikembangkan secara dinamis sesuai dengan tuntutan dan perubahan yang terjadi di masyarakat.

Upaya penyempurnaan kurikulum demi mewujudkan sistem pendidikan nasional yang kompetitif dan selalu relevan dengan perkembangan zaman yang senantiasa menjadi tuntutan. $\mathrm{Hal}$ ini sejalan dengan undang-undang nomor 20 tahun 2003 tentang sisdiknas pasal 35 dan 36 yang menekankan perlunya peningkatan standar nasional pendidikan sebagai acuan kurikulum secara berencana dan berkala dalam rangka mewujudkan tujuan pendidikan nasional.

Kurikulum 2013 adalah pembelajaran kompetensi dengan memperkuat proses pembelajaran dan penilaian autentik untuk mencapai kompetensi sikap, pengetahuan dan keterampilan. Penguatan proses pembelajaran dilakukan melalui pendekatan saintifik, yaitu pembelajaran yang mendorong peserta didik lebih mampu dalam mengamati, menanya, menalar, mencoba dan mengkomunikasikan (Mulyasa. E, 2013, h. 9).

Pendekatan saintifik mengingatkan kita bahwa pembelajaran bukan hanya diperolehnya sejumlah pengetahuan, keterampilan, dan sikap, tetapi yang lebih penting adalah bagaimana pengetahuan, keterampilan, dan sikap itu di peroleh peserta didik. Peneliti melihat pola pikir seperti ini belum dimiliki peserta didik, berdasarkan pemahaman peserta didik tentang pendekatan saintifik. Pembelajaran dengan pendekatan saintifik adalah pembelajaran yang terdiri atas kegiatan mengamati (untuk mengidentifikasi hal-hal yang ingin diketahui), merumuskan pertanyaan (dan merumuskan hipotesis), mencoba / mengumpulkan data (informasi) dengan berbagai teknik, mengasosiasi / menganalisis / mengolah data (informasi) dan menarik kesimpulan serta mengkomunikasikan hasil yang terdiri dari dari kesimpulan untuk memperoleh pengetahuan, keterampilan dan sikap.

IImu Pengetahuan Sosial merupakan mata pelajaran yang bersumber dari kehidupan sosial masyarakat yang diseleksi menggunakan konsep-konsep ilmu sosial yang digunakan untuk kepentingan pembelajaran. Keadaan sosial masyarakat selalu mengalami perubahan dari waktu ke waktu, dinamisasi kemajuan diberbagai bidang kehidupan harus dapat ditangkap dan diperhatikan oleh lembaga pendidikan yang kemudian menjadi bahan materi pembelajaran, Pembelajaran IPS bertujuan mengembangkan potensi peserta didik agar peka terhadap masalah sosial yang terjadi di masyarakat, memiliki sikap mental positif terhadap 
perbaikan segala ketimpangan yang terjadi, dan terampil mengatasi setiap masalah yang terjadi sehari-hari baik yang menimpa dirinya sendiri maupun yang menimpa kehidupan masyarakat" (Depdiknas, 2006, hlm.1).

Di SMP pendidikan IPS termasuk kelompok mata pelajaran IImu Pengetahuan dan Teknologi yaitu untuk mengenal, menyikapi, dan mengapresiasi ilmu pengetahuan dan teknologi, serta menanamkan kebiasaan berpikir dan berperilaku ilmiah yang kritis, kreatif dan mandiri (Maryani, 2011, hlm. 3).

IImu Pengetahuan Sosial (IPS) merupakan salah satu mata pelajaran yang diajarkan di SMP. Di kalangan siswa terdapat kecenderungan, bahwa mata pelajaran ini kurang diminati. Padahal mata pelajaran ini termasuk mata pelajaran yang di-UNkan. Menurut Adwiyarso (2008, hlm. 1) dalam Rusmawan (2013) Jurnal Cakrawala Pendidikan Juni 2013, Th. XXXII, No. 2 mengemukakan bahwa "cukup banyak siswa yang mengalami kesulitan dalam belajar menguasai materi ajar IPS. Kesulitan dalam belajar IPS lebih disebabkan tingkat minat baca yang rendah, serta ketergantungan siswa dalam belajar terhadap guru". Dalam mempelajari mata pelajaran IPS, siswa senantiasa dihadapkan pada situasi jenuh karena materi serta metode pengajaran yang kurang menarik dan monoton. Pengemasan materi pelajaran IPS ditentukan oleh strategi pembelajaran yang dilakukan oleh guru. Uno (2006, hlm. 45) mengemukakan bahwa strategi pembelajaran merupakan hal yang perlu diperhatikan guru dalam proses pembelajaran, paling tidak ada tiga jenis strategi yang berkaitan dengan pembelajaran, yakni strategi pengorganisasian pembelajaran, strategi penyampaian pembelajaran, dan strategi pengelolaan pembelajaran.

IPS mempunyai tugas mulia dan menjadi fondasi penting bagi pengembangan kecerdasan personal, sosial, emosional, dan intelektual. Melalui pembelajaran IPS peserta didik diharapkan mampu berpikir kritis, kreatif, dan inovatif. Sikap dan perilaku menunjukkan disiplin dan tanggung jawab selaku individual, warga masyarakat, warga negara, dan warga dunia. Mampu berkomunikasi, bekerjasama, memiliki sikap toleran, empati dan berwawasan multikultur dengan tetap berbasis keunggulan lokal. Memiliki keterampilan holistik, integratif dan transdisipliner dalam memecahkan masalah-masalah sosial. Tujuan tersebut dapat dicapai manakala program-program pembelajaran IPS di sekolah diorganisasikan dan dibelajarkan dengan penuh makna (meaningful learning) (Maryani, 2011, hlm 5).

Kurangnya minat siswa terhadap mata pelajaran ini, dimungkinkan karena belum optimalnya upaya guru untuk meningkatkan kreatifitas berpikir belajar siswa. Kebanyakan guru masih dominan menggunakan metode ceramah dalam mengajar sehingga tidak terciptanya proses pembelajaran yang menyenangkan dan bervariasi, yang dapat menambah semangat belajar siswa. Akibatnya, kegiatan belajar mengajar kurang menarik dan membosankan karena siswa tidak dirangsang atau ditantang untuk belajar dan berfikir kritis.

Dalam beberapa tahun terakhir, berpikir kritis telah menjadi suatu istilah yang sangat popular dalam strategi pembelajaran. Karena kegiatan pembelajaran di kelas lebih mengutamakan penerapan secara utuh dan realistik dari konsep yang akan dipelajari, melatihkan karakter ilmuwan yang cermat, kritis, kreatif, produktif dan mendorong siswa untuk: mengamati, mendeskripsikan, menanyakan, menganalisis, menggali informasi, menalar untuk mengambil kesimpulan (sementara) dan menciptakan sesuatu untuk disajikan, mengkomunikasikan hasil, dan merefleksikan proses belajarnya. Para pendidik diharuskan mengajarkan keterampilan-keterampilan berpikir dengan berbagai corak dari pada mengajarkan informasi dan isi. Sebagian besar pengajaran yang disampaikan kepada siswa adalah pada isi konten dari mata pelajaran dan banyak guru yang menyatakan bahwa guru telah mengajarkan kepada para siswanya tentang bagaimana berpikir, dan sebagian besar mengatakan bahwa guru menyampaikannya secara tidak langsung, yaitu sembari menyampaikan isi materi pelajaran. Lambat laun, para pendidik mulai meragukan efektivitas mengajarkan keterampilan-keterampilan berpikir dengan cara ini, karena hampir sebagian 
besar siswa sama sekali tidak memahami keterampilan-keterampilan berpikir yang dibicarakan. Maka dari itu guru harus semakin tertarik untuk mengajarkan keterampilanketerampilan ini secara langsung. Keterampilan tersebut adalah keterampilan berpikir kritis.

Alwasilah (dalam Pertiwi\&Nine, 2007, halm 7) menyatakan bahwa:

"lemahnya daya kritis-kreatif maha(siswa) Indonesia selama ini terpulang kepada dua hal, yaitu kultur tradisional serta praktik pendidikan. Mayoritas responden (mahasiswa Indonesia di AS) menyatakan, bahwa pendidikan yang diperolehnya di Indonesia tidak membekali mereka kemampuan berpikir kritis dan menyadari, bahwa menulis akademik dan presentasi di depan kelas merupakan tugas akademik yang paling sulit bagi mereka. Kesulitan serupa dialami pula mahasiswa Indonesia yang berkuliah di Australia. Di Australia mereka merasa beruntung dilatih mengembangkan keterampilan berpikir kritis ketika membaca teks sesuatu yang tidak diajarkan di Indonesia. Siswa SD sampai SMA bahkan mahasiswa S1 di Indonesia kurang kritis karena tiga hal: pengaruh budaya tradisonal, guru dan dosen tidak tahu cara mengajarkan berpikir kritis, dan rendahnya kemampuan dosen dan mahasiswa. Bahkan secara keseluruhan masyarakat Indonesia dinilai kurang kritis karena tiga hal: warisan budaya tradisional, rendahnya kadar demokrasi dalam pemerintahan Indonesia, dan rendahnya populasi yang berpendidikan."

Kemampuan berpikir kritis bermanfaat untuk beradaptasi dengan situasi baru. Karena, bila seseorang diajarkan tentang berpikir kritis maka ia akan selalu dapat beradaptasi dengan situasi apapun. Pentingnya melatihkan keterampilan berpikir kritis di sekolah, karena berpikir kritis merupakan proses yang memungkinkan peserta didik menanggulangi dan mereduksi ketidakmenentuan di masa datang. Cabrera (1992) dalam Wayan (2013, hlm 12) dengan berpikir kritis memungkinkan peserta didik menentukan informasi yang penting didapatkan, diubah atau ditransformasi, dan dipertahankan. Dengan berpikir kritis pula, peserta didik dapat mengatur, menyesuaikan, mengubah atau memperbaiki pikirannya, sehingga peserta didik dapat bertindak lebih cepat. Peserta didik yang berpikir kritis adalah peserta didik yang dapat memecahkan masalah-masalah yang dihadapi dalam kehidupan sehari-hari dan dapat menghadapi tantangan.

Dari hasil rujukan di atas dapat diketahui bahwa pendekatan saintifik memiliki pengaruh terhadap minat belajar siswa. Oleh karena itu penulis melakukan penelitian lebih menekankan kepada efektivitas pembelajaran pendekatan saintifik terhadap kemampuan berfikir kritis peserta didik sehingga dapat diketahui sejauh mana pencapaian kemampuan berfikir peserta didik pada mata pelajaran IPS kelas VII di SMPN 1 Pacet Cianjur.

\section{LANDASAN TEORI}

pembelajaran dengan pendekatan saintifik mempunyai kriteria, dimana proses pembelajaran terhindar dari tafsiran-tafsiran semata serta harus bersifat kontekstual atau berdasar akan fakta dan data yang benar terjadi di lingkungan sekitar. Interaksi di dalam kelas pun harus terhindar dari penalaran atau menduga-duga mengenai materi yang di sampaikan guru di dalam kelas. Pembelajaran dengan pendekatan saintifik ini juga diharapkan agar peserta didik dapat meningkatkan proses berfikir kritis, analitis, mengidentifikasi dan memecahkan suatu masalah. Guru harus dapat mendorong peserta didik dalam berfikir hipotetik terhadap proses pembelajaran peserta didik. Konsep, teori serta fakta empiris merupakan suatu yang akan terus beriringan selama kegiatan pembelajaran berlangsung dan hal tersebut menjadi dasar untuk pertanggungjawaban mengenai materi yang telah disampaikan. Tujuan pembelajaran dikemas sedemikian rupa secara jelas dan sederhana sehingga peserta didik merasakan bahwa pembelajaran itu dapat menyenangkan.

Proses pembelajaran pada kurikulum 2013 untuk semua jenjang dilaksanakan dengan menggunakan pendekatan ilmiah (saintifik). Langkah-langkah pendekatan saintifik dalam proses pembelajaran meliputi menggali informasi melalui pengamatan, bertanya, percobaan, 
kemudian mengolah data atau informasi, menyajikan data atau informasi, dilanjutkan dengan menganalisis, menalar, kemudian menyimpulkan, mencipta, dan mengkomunikasikan / membuat jejaring.

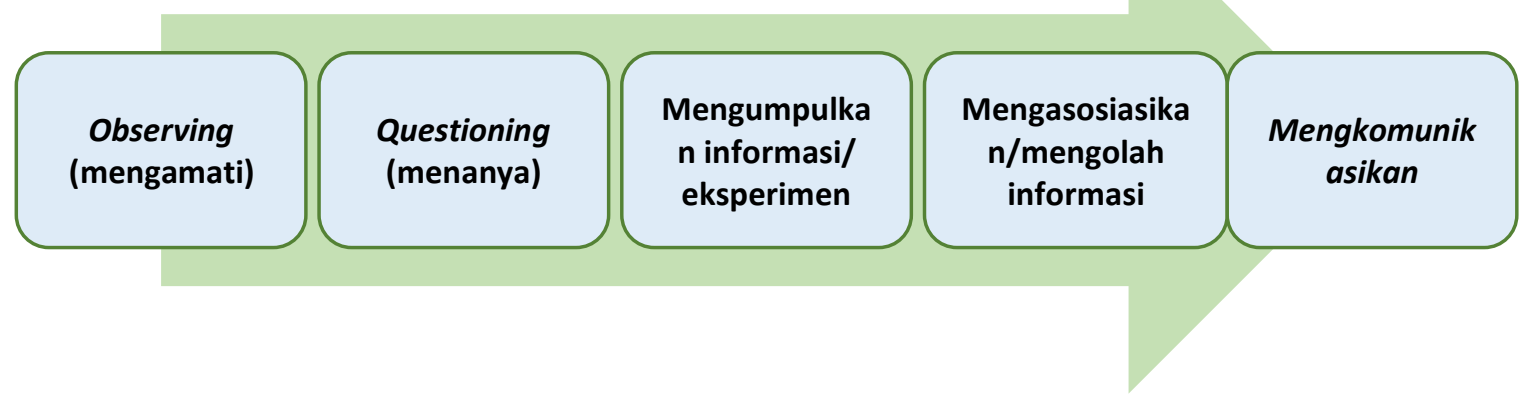

Sumber: Daryanto, 2014, Pendekatan Pembelajaran Saintifik Kurikulum 2103, h.59.

Gambar 2.2

Langkah-Langkah Pendekatan Saintifik

Langkah Pendekatan Saintifik (PERMENDIKBUD 81A). Proses pembelajaran terdiri atas lima pengalaman belajar pokok yaitu:

a. mengamati;

b. menanya;

c. mengumpulkan informasi

d. mengasosiasi

e. mengkomunikasikan

Menurut Dewey (dalam Sihotang, 2012, hlm. 4-5) menjelaskan ciri utama dari berpikir aktif, yakni berpikir secara terus-menerus dan teliti. Dalam arti itu dapat disimpulkan bahwa orang yang berpikir kritis akan terus aktif mengoptimalkan daya nalarnya, tidak mau menerima sesuatu begitu saja, dan selalu mencermati berbagai informasi atau pengetahuan yang menjadi objek pemikirannya. Apa yang dikatakan John Dewey di atas mendapat penjelasan lebih lanjut dalam pemikiran Edward Glaser mengenai tentang hal yang sama. Glaser (1941) berpendapat bahwa seseorang dapat dikatakan memiliki kemampuan berpikir kritis, jika kerja nalar dan kemampuan argumentasinya melibatkan tiga hal, yakni

1) Sikap menanggapi berbagai persoalan, menimbang berbagai persoalan yang dihadapi dalam pengalaman dan kemampuan memikirkannya secara mendalam. Sikap dan kemampuan ini bertujuan untuk membebaskan seseorang dari kebiasaan menerima berbagai informasi atau kesimpulan tanpa mempertanyakannya.

2) Pengetahuan akan metode berpikir/bernalar dan inkuari logis.

3) Keterampilan atau kecakapan menerapkan metode-metode tersebut.

Berangkat dari apa yang dikatakan Edward Glaser, dapat disimpulkan bahwa:

1) Kemampuan berpikir kritis menuntut adanya usaha untuk selalu menguji keyakinan atau pengetahuan apa pun dengan cara mempertanyakan sejauh mana keyakinan atau pengetahuan itu didukung oleh data (evidence). Ini penting untuk menguji kesahihan kesimpulan dari keyakinan atau pengetahuan tersebut.

2) Berpikir juga menuntut adanya kemampuan untuk mengenali, mengidentifikasi, dan memahami persoalan serta menemukan solusi atasnya. Kemampuan ini dituntut supaya 
seseorang dapat mengumpulkan informasi yang dibutuhkan atau data-data yang dituntut demi memecahkan masalah tersebut.

3) Kemampuan mengidentifikasi atau menemukan hubungan antarberbagai proposisi, menarik kesimpulan-kesimpulan atau generalisasi-generalisasi, menguji kembali kesimpulan yang telah diambil, serta mempertanyakan kembali keyakinan dan pengetahuan yang selama ini diterima begitu saja.

Hal ini seperti yang dikemukakan Sedangkan menurut Ennis (1996) Ennis (1996) (dalam Fisher, 2009, hlm. 4) berpikir kritis adalah sebuah proses yang dalam mengungkapakan tujuan yang dilengkapi alasan yang tegas tentang suatu kepercayaan dan kegiatan yang telah dilakukan. Berpikir kritis sangat penting, karena dengan sangat hati-hati dalam mengambil keputusan, memberi makna terhadap suatu isu atau peristiwa tertentu, dan melahirkan suatu pemecahan masalah.

\section{METODOLOGI}

Pada penelitian ini, untuk mengetahui peningkatan kemampuan berpikir kritis Peserta didik melalui pembelajaran IPS pendekatan saintifik, dilaksanakan penelitian dengan menggunakan metode kuasi eksperimen. Kuasi Eksperimen dalam penelitian ini dilaksankan dengan menggunakan desain-desain tertentu. Pemilihan suatu desain didasarkan atas keefektifannya baik dalam mengungkap temuan yang terkait dengan hubungan kausal maupun dalam menjamin terhindarnya kesimpulan dari ancaman-ancaman terhadap kevalidan, baik kevalidan internal maupun kevalidan eksternal.

Penelitian ini dapat dikategorikan sebagai penelitian Kuasi eksperimental dengan tujuan untuk mengetahui variabel sebab dan varibel akibat, yaitu pengaruh dari membangun hubungan positif pendekatan saintifik terhadap kemampuan berpikir kritis siswa.

Desain yang digunakan dalam penelitian ini adalah desain kelompok tunggal dengan pretes dan postes atau One Group Pre-test and post test Design (Ali dan Asrori (2014, hlm. 81-82). Jenis eksperimen yang digunakan dalam penelitian ini adalah pre-eksperimental design. Dikatakan pre-eksperimental design karena desain ini belum merupakan eksperimen sungguh-sungguh karena masih terdapat varibel luar yang ikut berpengaruh terhadap terbentuknya varibel dependen, yang pelaksanaanya dilakukan dengan memilih secara ramdom satu kelompok, dan terhadap kelompok itu diberikan tes awal sebelum diberikannya perlakuan atau pre-test (O1), kemudian kelompok itu diberi perlakuan (X), dan pasca diberikan perlakuan dilakukan post test (O2).

\section{HASIL DAN PEMBAHASAN}

Hipotesis hasil uji t pada penelitian desain kelompok tunggal dengan pre-test dan posttest. Dalam menganalisis hasil pre-test dan post test, peneliti menggunakan software IBM SPSS Statistic 20 for windows. Berikut hasil uji hipotesis pada saat pre-test dan post test:

Tabel 4.24

Uji Perbedaan Rata-rata Skor Pre-Test dan Post Test

Paired Samples Test

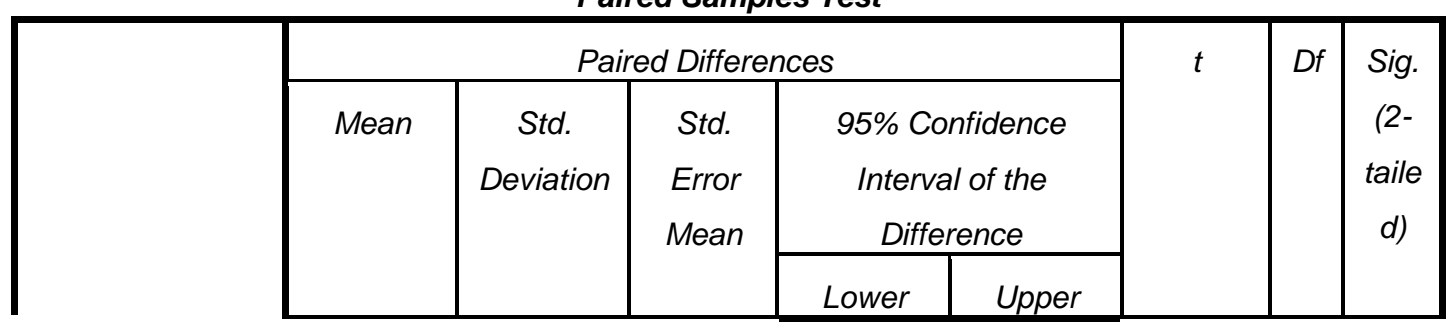




\begin{tabular}{|ll|l|l|l|l|l|l|l|l|}
\hline Pair $1 \begin{array}{l}\text { Pretest - } \\
\text { Posttest }\end{array}$ & 15,78947 & 7,46852 & 1,21155 & 18,24432 & 13,33463 & 13,032 & 37 &, 000 \\
\hline
\end{tabular}

Sumber data primer : software IBM SPSS Statistic 20 for windows

Dari hasil uji t berpasangan tersebut terlihat bahwa rata-rata perbedaan antara pre-test dengan post test adalah sebesar 15,8. Artinya ada peningkatan kemampuan berpikir kritis sesudah diterapakannya pembelajaran pendekatan saintifik dengan rata-rata peningkatan 15,8. Hasil perhitungan nilai " $t$ " adalah sebesar 13,032 dengan $p$ value 0,000 (uji dua arah). Hal ini berarti Ho ditolak dan menyimpulkan bahwa secara statistik ada perbedaan antara nilai pada saat pre- test dan post test.

Kemampuan bepikir kritis peserta didik pada kelas VIII di SMPN 1 Pacet Cianjur berdasarkan pada analisis data hasil pre-test dan post test menunjukkan bahwa terdapat perbedaan kemampuan berpikir kritis peserta didik antara sebelum dan sesudah diberikan perlakuan yang menggunakan pembelajaran pendekatan saintifik dengan kriteria penilaian peningkatan dikategorikan cukup. Hal tersebut dapat dilihat dengan adanya perbedaan ratarata skor gain kemampuan berpikir kritis peserta didik dalam kompetensi dasar mendeskripsikan permintaan, penawaran, pasar, dan harga sebesar 0,33. sesuai dengan hasil penelitian sebelumnnya seperti Indriana Fristanti (2011) yang mengimpelementasikan metode pembelajaran pendekatan saintifik efektif dalam meningkatkan kemampuan berpikir kritis peserta didik. Darmawan (2010) yang meneliti dampak dari pembelajaran pendekatan saintifik terhadap kemampuan berpikir kritis peserta didik. Kedua penelitian tersebut memperoleh hasil yang menunjukkan bahwa metode pembelajaran pendekatan saintifik mampu meningkatkan kemampuan berpikir kritis peserta didik.

\section{PENUTUP}

Terdapat perbedaan nilai rata-rata kemampuan berpikir kritis peserta didik antara sebelum dan sesudah perlakuan pada kelas VII D yang terlihat pada nilai pre-test dan post test dan dibuktikan dengan uji hipotesis. Dibandingkan antara sebelum dan setelah perlakuan pada kelas VII D, kemampuan bepikir kritis peserta didik dalam mata pelajaran IPS untuk kompetensi dasar memahami permintaan, penawaran, pasar, dan harga sangat nyata meningkat setelah diberikan perlakuan dengan menggunakan pembelajaran pendekatan saintifik. Maka dapat disimpulkan bahwa pembelajaran pendekatan saintifik berpengaruh secara positif terhadap kemampuan berpikir kritis peserta didik. Hal ini diperkuat oleh pendapat peserta didik kelas VII D SMPN 1 Pacet Cianjur tentang pelaksanaan pembelajaran pendekatan saintifik yang berada pada kriteria baik. Namun, untuk dimensi mengembangkan dan mepresentasikan artefak belum optimal. Hal ini digambarkan dalam pernyataan saya bersama kelompok membuat model (perwujudan secara fisik dari situasi masalah dan pemecahannya). Dan pendapat peserta didik kelas VII D SMPN 1 Pacet Cianjur tentang kemampuan berpikir kritis pada kriteria baik. Indikator berpikir kritis peserta didik yang paling baik menurut peserta didik di SMPN 1 Pacet Cianjur adalah membangun keterampilan dasar. Indikator berpikir kritis yang paling rendah menurut Peserta Didik di SMPN 1 Pacet Cianjur adalah memberikan penjelasan dasar.

\section{DAFTAR PUSTAKA}

Ali, M,. \& Asrori. (2014) Metodologi \& Aplikasi Riset Pendidikan. Jakarta: Bumi Aksara Arends, R. (2008). Learning To Teach edisi ke tujuh buku 2. Yogyakarta: Pustaka Pelajar. Arikunto, Suharsimi.(2013). Manajemen Penelitian. Jakarta: Rineka Cipta.

Affandi, I. (2012). Strategi Mengajar Ilmu Sosial terjemahan dari buku James A Banks Teaching Strategeis for the Social Studies: Inquary, Valuaing, and Decision-Marking. 
New York: Logman.

Bayer. B. K. (1971). Inquiry in the Social Studies Classroom; A Strategy for Teaching. Columbus, OH: Charles E Merril Publ. Co.

Costa, A. L. (1985). Developing Minds. A resource Book for Teaching Thingking. Association for Supervision and Curriculum Development. Virginia: Alexandria.

Daryanto, (2014). Pendekatan Pembelajaran Saintifik Kurikulum 2013. Yogyakarta: Gava Media.

Depdiknas (2008) Kamus Besar Bahasa Indonesia. Jakarta. Balai Pustaka

Ennis, R.H. (1996) Critical Thinking. New Jersey: simon \& Schuser/A Vlacom Company

Eggen, P. \& Kauchak, D. (2012). Strategi dan Model Pembelajaran. Jakarta: Indeks.

Filsaime, D. K. (2008). Menguak Rahasia Berpikir Kritis dan Kreatif. Jakarta: Prestasi Pustaka.

Fisher, A. (2009). Berpikir Kritis Sebuah Pengantar. Jakarta: Elangga.

Gintings, A, (2012). Esensi Praktis Belajar dan Pembelajaran Edisi Revisi. Bandung: Humaniora.

Hamied, F.A. \& Komar, O. (2013) Filsafat IImu. Bandung: Sekolah Pascasarjana Universitas Pendidikan Indonesia.

Hermawan, A. (2009). Penelitian Bisnis Paradigma Kuantitatif. Jakarta: Gramedia Widiasarana Indonesia.

Hosnan, M. (2014). Pendekatan Saintifik dan Konstekstual dalam pembelajaran abad 21. Bogor. Ghalia Indonesia.

Joyce, B., Weil, M., \& Calhoun, E. (2009). Models of Teaching.Model-Model

Pengajaran. Edisi Kedelapan. Terjemahan Achmad Fawaid dan Ateilla Mirza. Yogyakarta: PustakaPelajar.

Komalasari, K. (2013). Pembelajaran Kontekstual Konsep dan Aplikasi. Bandung: Refika Aditama.

Kusnendi,.Suryadi, E.( 2005). Panduan Operasional Metode Penelitian Ilmiah. Bandung: Universitas Pendidikan Indonesia.

Maryani, E. (2011). Pengembangan Program Pembelajaran IPS Untuk Peningkatan Keterampilan Sosial. Bandung: Alfabeta.

Matthew, Olson, H. \& Hergenhahn, B.R. (2008). Theories Of Learning (Teori Belajar dialih bahasakan oleh Tri Wibowo B.S). Jakarta : Prenada Media Group.

Molan, B. (2012). Logika Ilmu dan Seni Berpikir Kritis. Jakarta: PT Indeks Permata Puri Media

Nur, M. (2005). Pembelajaran Kooperatif. Departemen Pendidikan Nasional Direktorat Pendidikan Dasar dan Menengah Lembaga Penjamin Mutu Jawa Timur.

Pannen, Paulina \& Purwanto. (2001). Penulisan Bahan Ajar. Jakarta: Pusat antar Universitas untuk Peningkatan dan Pengembangan Aktivitas Intruktional Ditjen Dikti Diknas.

Pertiwi, P. (2009). Menulis Esai \& Pembelajarannya. Bandung: Prisma Press.

PSG. Pendidikan Latihan Profesi Guru. Periode 4 Lokasi Hotel Bakti Asih (2014) Rayon 134 Universitas Pasundan Bandung.

Rahyubi, H. (2012). Teori-teori Belajar dan Aplikasi Pembelajaran Motorik. Bandung : Nusa Media

Ridwan. (2004). Belajar Mudah Penelitian Untuk Guru-Karyawan dan Peneliti Pemula. Bandung: Alfabeta.

Riyanto, Y. (2012). Paradigma Baru Pembelajaran. Surabaya : Kencana Prenada Media Group.

Ruseffendi. (2005). Dasar-dasar Penelitian Pendidikan \& Bidang Non-Eksata Lainnya. Bandung: Tarsito.

Rusman. (2010). Seri Manajemen Sekolah Bermutu Model-Model Pembelajaran Pengembangkan Profesionalisme Guru. Jakarta: Raja Grafindo Persada.

(2012). Model - Model Pembelajaran. Depok : PT Rajagrafindo Persada 
Rusmono. (2012). Strategi Pembelajaran dengan Problem Based Learning itu perlu. Jakarta : Ghalia Indonesia.

Santoso, Singgih,.Tjiptono, F. (2001). Riset Pemasaran, Konsep dan Aplikasi dengan SPSS. Jakarta: PT. Alex Media Komputindo

Santrock, J.W. (2009). Psikologi Pendidikan (Terjemahan). Jakarta : Salemba Humanika

Sapriya,. Nurdin, S,.Susilawati. (2008). Konsep Dasar IPS. Bandung: CV Yasindo Multi Aspek.

Sihotang, K,. dkk. (2012). Critical Thinking Membangun Pemikiran Logis. Jakarta: Pustaka Sinar Harapan.

Somantri, N. (2001). Menggagas Pembaharuan Pendidikan IPS. Bandung: Remaja Rosdakarya.

Sugiyono. (2008). Metode Penelitian Bisnis. Bandung: Alfabeta.

Sudjana \& Ibrahim. (2004). Penelitian dan Penilaian Pendidikan. Bandung: Sinar Baru Algensindo.

Sudjana, N. (2010). Penilaian Hasil Proses Belajar Mengajar. Bandung: PT. Remaja Rosdakarya.

Sudjana, S. (2010). Strategi Pembelajaran. Bandung: Falah Prodution.

Sukmadinata \& Syaodih, N. (1997). Pengembangan Kurikulum, Teori dan Praktek. Bandung: PT Remaja Rosdakarya.

Sunaryo. (1989). Evaluasi Hasil Belajar. Jakarta: P2LPTK Dikti, Depdikbud.

Syamsusddin, M.A. (2009). Psikologi Pendidikan Perangkat Sistem Pengajaran Modul. Bandung: PT Remaja Rosdakarya.

Syamsulbachri, A. ,Iskandar, D. \& Sulipan. (2009). Bahan Ajar PLPG Ilmu Pengetahuan Sosial untuk SMP. Rayon 34 Universitas Pasundan. Bandung: FKIP Universitas Pasundan.

Trianto. (2009). Mendesain Model Pembelajaran Inovatif-Progresif. Jakarta: Fajar Inter Pratama Mandiri. 